\title{
Capacidade relacional e geração de inovações em empresas de base tecnológica
}

João Marcos Silva de Almeida

Pós-Graduação em Administração da Qualidade pela Fundação Escola de Comercio Alvares Penteado. professor dos cursos de Administração, Tecnologia em Marketing e Gestão Comercial na Universidade Nove de Julho

joaomarcos.a@uol.com.br

Priscila Rezende da Costa

Doutora em Administração pela Universidade de São Paulo

Professora Titular da Universidade Nove de Julho (UNINOVE)

priscilarezende@yahoo.com.br

Editor Científico: José Edson Lara

Organização Comitê Científico

Double Blind Review pelo SEER/OJS

Recebido em 19.02.2018

Aprovado em 24.09.2018 


\title{
Resumo
}

O desenvolvimento da capacidade relacional (CA) a partir das alianças estratégicas de pesquisa e desenvolvimento $(\mathrm{P} \& \mathrm{D})$ pode gerar diferenciais competitivos em empresas de base tecnológica (EBTs). Diante deste contexto, objetivo geral foi analisar de que forma a capacidade relacional pode contribuir para a geração de inovações em EBTs. De forma específica, buscou-se nas EBTs de Biotecnologia: (a) verificar como ocorre a geração de inovações nestas empresas e (b) identificar as propriedades da capacidade relacional que contribuem para a geração de inovações biotecnológicas. Para tal, delineou-se uma pesquisa descritiva de natureza qualitativa realizada a partir de estudo de caso múltiplo com quatro EBTs de biotecnologia. Dados primários foram coletados a partir de entrevistas estruturadas e dados secundários foram obtidos a partir de documentos organizacionais, incluindo contratos, projetos e relatórios de desenvolvimento de novos produtos. Adotou-se análise de conteúdo para interpretar os dados e foi utilizada uma estratégia analítica baseada em proposições teóricas que conduziram as discussões. Além disso, adotou-se o software Iramuteq para recuperação de corpus textuais e palavras. Sobre a justificativa, destaca-se que o trabalho oportunizou a análise sobre como as EBTs de biotecnologia planejam, estruturam, coordenam e sincronizam as alianças estratégicas contratuais. De forma específica, os resultados agregados possibilitaram a identificação de propriedades descritoras da capacidade relacional que estimulam e sistematizam a geração de inovações. A conclusão foi de que a capacidade relacional desempenha um papel fundamental para a agregação de valor ao modelo de negócios fundamentado em alianças estratégicas contratuais.

Palavras-chave: Capacidade Relacional, Aliança Estratégica, Inovação, Empresas de Base Tecnológica.

\section{Relational Capacity and Innovation Generation in Technology-Based Enterprises}

\begin{abstract}
The development of relational capacity (CA) from strategic $R \& D$ alliances can generate competitive differentials in technology-based companies (EBTs). Given this context, the general objective was to analyze how relational capacity can contribute to the generation of innovations in EBTs. Specifically, the EBTs of Biotechnology were sought: (a) to verify how the generation of innovations in these companies occurs and (b) to identify the properties of the relational capacity that contribute to the generation of biotechnological innovations. For that, a qualitative descriptive research was performed based on a multiple case study with four biotechnology EBTs. Primary data were collected from structured interviews and secondary data were obtained from organizational documents, including contracts, projects and reports of new product development. Content analysis was used to interpret the data and an analytical strategy based on the theoretical propositions that led the discussions was used. In addition, Iramuteq software was used to retrieve textual corpus and words. Regarding the justification, it is worth noting that the study provided an opportunity to analyze how biotechnology EBTs plan, structure, coordinate and synchronize strategic contractual alliances. Specifically, the aggregate results enabled the identification of descriptive properties of the relational capacity that stimulate and systematize the generation of innovations. The conclusion was that relational capability plays a key role in aggregating value to the business model based on strategic contractual alliances.
\end{abstract}

Keywords: Relational Capacity, Strategic Alliance, Innovation, Technology-Based Companies 


\section{Capacidad Relacional y Generación de Innovaciones en Empresas de Base Tecnológica}

\section{Resumen}

El desarrollo de la capacidad relacional (CA) a partir de las alianzas estratégicas de investigación y desarrollo (I\&D) puede generar diferenciales competitivos en empresas de base tecnológica (EBTs). Ante este contexto, objetivo general fue analizar de qué forma la capacidad relacional puede contribuir a la generación de innovaciones en EBTs. De forma específica, se buscó en las EBTs de Biotecnología: (a) verificar como ocurre la generación de innovaciones en estas empresas y (b) identificar las propiedades de la capacidad relacional que contribuyen a la generación de innovaciones biotecnológicas. Para ello, se delineó una investigación descriptiva de naturaleza cualitativa realizada a partir de un estudio de caso múltiple con cuatro EBTs de biotecnología. Los datos primarios fueron recolectados a partir de entrevistas estructuradas y datos secundarios fueron obtenidos a partir de documentos organizativos, incluyendo contratos, proyectos e informes de desarrollo de nuevos productos. Se adoptó análisis de contenido para interpretar los datos y se utilizó una estrategia analítica basada en proposiciones teóricas que condujeron a las discusiones. Además, se adoptó el software Iramuteq para recuperación de corpus textuales y palabras. Sobre la justificación, se destaca que el trabajo oportunizó el análisis sobre cómo las EBTs de biotecnología planean, estructuran, coordinan y sincronizan las alianzas estratégicas contractuales. De forma específica, los resultados agregados posibilitar la identificación de propiedades descriptoras de la capacidad relacional que estimulan y sistematizan la generación de innovaciones. La conclusión fue que la capacidad relacional desempeña un papel fundamental para la agregación de valor al modelo de negocios fundamentado en alianzas estratégicas contractuales.

Palabras claves: Capacidad Relacional, Alianza Estratégica, Innovación, Empresas de Base Tecnológica.

\section{Introdução}

As EBTs desempenham importante papel tanto para a modernização do parque produtivo nacional, como para a constituição de novos mercados e de novas atividades. (Fernandes, Côrtes \& Pinho, 2016), são também conhecidas por outras denominações, como: empresas de alta tecnologia, empresas orientadas para tecnologias, empresas intensivas em tecnologias e empresas de tecnologia (Grinstein \& Goldman, 2006).

Para o Ministério da Ciência e Tecnologia (2016), as EBTs são definidas como organizações que fundamentam suas atividades no desenvolvimento de novos produtos e/ou processos baseados na aplicação sistemática de conhecimentos científicos e tecnológicos e na utilização de técnicas avançadas.

As EBTs devem desenvolver diferenciais competitivos para a geração de inovações com vistas a garantir um posicionamento distinto em ambientes turbulentos e de constantes mudanças, e é 
justamente na capacidade relacional, ou seja, na capacidade que as empresas têm de se relacionar com outras organizações, além de suas fronteiras, que as EBTs encontram a possibilidade de expandir seus recursos e obter novas competências (Fernandes, Côrtes, \& Pinho, 2016).

Uma das formas de relacionamento são as alianças estratégicas que consistem basicamente em acordos contratuais com os quais as empresas, em nome de suas necessidades, buscam cooperar com atores externos, procurando encontrar ou ampliar a sua base de recursos, tendo em vista atingirem objetivos comuns de P\&D e geração de valor a partir da inovação (Ortiz-de-Urbina-Criado, MontoroSánchez, \& Mora-Valentín, 2014).

As alianças estratégicas contratuais focadas em inovação é uma abordagem cujo fundamento central baseia-se no conceito de capacidade dinâmica, ou seja, a capacidade de uma organização de criar, ampliar ou transformar a base de recursos para alcançar e sustentar vantagens competitivas em ambientes de mudanças (Teece, Pisano \& Shuen, 1997; Helfat, Finkelstein, Mitchell, Peteraf, Singh, Teece, \& Winter, 2009).

Schilke e Goerzen (2010) descrevem a capacidade relacional como uma capacidade dinâmica das organizações composta por ativos, habilidades individuais e rotinas, constituindo um conjunto de atividades que permite à empresa criar, ampliar ou modificar a sua base de recursos a partir da interação com seus parceiros.

Quanto aos setores potencialmente aderentes e relevantes à realização de estudos empíricos sobre a temática capacidade relacional, destaca-se o de biotecnologia. Estrella e Bataglia (2013) enfatizam que as empresas de biotecnologia desenvolveram ao longo dos anos um sistema complexo de alianças contratuais com diversas organizações que compõem seu campo de atuação: universidades, institutos de pesquisa, fundos de investimento, agências governamentais, laboratórios farmacêuticos e outras empresas de biotecnologia.

Observa-se que a diversidade científica e tecnológica, a integração das atividades de P\&D, bem como a multidisciplinaridade dos conhecimentos gerados, contribuem para que as EBTs de biotecnologia busquem de forma contínua e colaborativa a inovação em seus produtos. Sendo assim, o amadurecimento da capacidade relacional a partir das alianças estratégicas pode ser relevante para a conquista de diferenciais competitivos.

Diante desse contexto, torna-se latente, nas EBTs do setor de biotecnologia, a necessidade de potencializar a gestão das alianças estratégicas contratuais focadas em inovação, visando ao aprimoramento da capacidade relacional para geração de inovações. 
Procura-se, com a realização deste estudo, responder à seguinte questão de pesquisa: Como a capacidade relacional pode contribuir para a geração de inovações em EBTs? O objetivo geral é analisar de que forma a capacidade relacional pode contribuir para a geração de inovações em EBTs. De forma específica, busca-se nas EBTs de Biotecnologia: (a) verificar como ocorre a geração de inovações nestas empresas e (b) identificar as propriedades da capacidade relacional que contribuem para a geração de inovações biotecnológicas.

Pode-se observar neste estudo contribuições para o avanço do conhecimento, especificamente, no que tange a análise aprofundada da capacidade relacional das EBTs de biotecnologia, dado que elas atuam em um sistema colaborativo de $\mathrm{P} \& \mathrm{D}$, em que as empresas e parceiros se relacionam para buscar novas oportunidades, recursos, conhecimentos e tecnologias.

\section{Referencial Teórico}

Zollo e Winter (2002) descrevem a existência de dois conjuntos de atividades que estão relacionados ao conceito de capacidades, a saber: primeiro, as atividades voltadas para as funções operacionais que são chamadas de rotinas operacionais; segundo as atividades voltadas às mudanças das rotinas operacionais, que são chamadas de capacidades dinâmicas (Camargo \& Meirelles, 2012; Wang, Dou, Zhu, \& Zhou, 2015; Alves, 2015).

O conceito de capacidades dinâmicas engloba também as capacidades relacionais, que ocorrem quando duas ou mais organizações têm a necessidade de cooperar entre si para buscar novos recursos e competências que, em princípio, não possuem dentro de suas próprias fronteiras organizacionais (Wang \& Rajagopalan, 2015; Delbufalo \& Cerruti, 2012; Costa, Porto \& Silva, 2012).

Lorenzoni e Lipparini (1999) e Schilke e Goerzen (2010) consideram a capacidade relacional como dinâmica e que essa capacidade contribui para o desenvolvimento de sua base de recursos a partir de parcerias formais e intencionais.

Gibbons e Henderson (2012) afirmam que a obtenção de uma capacidade competitiva pode depender de práticas gerenciais sustentadas por contratos relacionais e que a formalização pode contribuir para resolver dois problemas existentes nos relacionamentos organizacionais: credibilidade e transparência.

A repetição das alianças faz com que as empresas adquiram maior experiência nesse processo, permitindo, ao longo do tempo, que não somente a empresa, mas, também, seus funcionários aprendam com as experiências anteriores, o que contribui para o desenvolvimento e melhoria de suas 
rotinas e processos organizacionais, aumentando a capacidade relacional da empresa (Anderson, Benavides-Espinosa, \& Mohedano-Suanes, 2011).

Sobre a evolução das discussões científicas de capacidade relacional, vale destacar os modelos de McGrath (2008), Schilke e Goerzen (2010) e Alves (2015), utilizados como base para o desenvolvimento deste trabalho e descritas a seguir:

O modelo conceitual proposto por Schilke e Goerzen (2010) estabelece dois importantes fatores que influenciam o desenvolvimento da capacidade relacional, a saber: (1) o primeiro fator diz respeito às experiências prévias acumuladas de alianças anteriores e a consequente influência na criação de rotinas que ajudam a gerenciar as novas alianças; (2) o segundo fator refere-se à estrutura da aliança, que é definida como unidades organizacionais constituídas para essa função, o que envolve um conjunto de pessoas especializadas e dedicadas à gestão das alianças estratégicas.

Adicionalmente a experiência prévia acumulada e da estrutura da aliança, Schilke e Goerzen (2010) estabeleceram rotinas que influenciavam a gestão da capacidade relacional, sendo elas: Coordenação interorganizacional, Coordenação do portfólio da aliança, Aprendizado interorganizacional, Proatividade e Transformação da aliança.

Quanto as dimensões da capacidade relacional discutidas por McGrath (2008) destacamse: Acesso à dimensão do conhecimento, Dimensão de avaliação, Dimensão da coadaptação, Dimensão da coinovação, Acesso à dimensão da oportunidade e Dimensão da realização.

Alves (2015), por sua vez, reorganizou o constructo "capacidade relacional" e agrupou por similaridade as dimensões propostas por Schilke e Goerzen (2010), McGrath (2008) e Sarkar, Aulakh e Madhok (2009), que resultaram nas seguintes dimensões: Dimensão de coordenação, Dimensão cultural, Dimensão do conhecimento, Dimensão tecnológica e Dimensão de coadaptação.

\section{Método}

Delineou-se uma pesquisa descritiva (Barros \& Lehfeld, 2007) de natureza qualitativa (Biklen \& Bogdan, 1994; Richardson, 1999). Sobre o método, adotou-se o estudo de caso múltiplo (Yin, 2010) com quatro microempresas de biotecnologia de capital privado que estabelecem dinamicamente parcerias com universidades, institutos de pesquisa, representantes comerciais e/ou clientes nacionais e internacionais, cujo foco estratégico é a inovação. 
Cabe ressaltar que a unidade de análise foi representada pelas EBTs do setor de biotecnologia, pois são empresas que buscam, a partir de parcerias externas, obter novos recursos ou recursos complementares ao desenvolvimento de produtos inovadores. Para a identificação de empresas de biotecnologia, considerou-se o conceito de biotecnologia proposto pela OCDE (2005), a saber: aplicação da ciência e da tecnologia aos organismos vivos, bem como partes, produtos e modelos oriundos desses organismos, para alterar materiais vivos ou não para produção de conhecimento, bens e serviços.

A partir desta definição, foi realizada uma prospecção para identificar os principais parques tecnológicos da região Sudeste do Brasil (região com maior número de empresas no setor de biotecnologia, segundo o relatório do Brazil Biotech Map da CEBRAP de 2011), bem como as principais EBTs de biotecnologia instaladas. Posteriormente, deu-se início ao contato com os seguintes parques: BIO-RIO, com aproximadamente 21 empresas; polo de biotecnologia de São Paulo, onde está localizado o Centro de Inovação, Empreendedorismo e Tecnologia (Cietec), com 16 empresas; polo de biotecnologia de Campinas, onde está localizada a Companhia de Desenvolvimento do Polo de Alta Tecnologia de Campinas (Ciatec), com 10 empresas; e o Supera Parque de Inovação e Tecnologia de Ribeirão Preto, com 36 empresas. Por fim, solicitou-se aos gestores destes parques indicações de EBTs de biotecnologia de destaque em termos de desenvolvimento de novos produtos e processos biotecnológicos, sendo as empresas indicadas e, posteriormente, selecionadas para investigação as descritas na figura 1 :

\begin{tabular}{|c|c|}
\hline Empresas & Caracterização \\
\hline Biotika & $\begin{array}{c}\text { Especializada na importação e distribuição de reagentes e equipamentos inovativos em } \\
\text { biotecnologia para instituições e profissionais de pesquisa científica }\end{array}$ \\
\hline Gentros & $\begin{array}{c}\text { Especializada na tecnologia de proteínas recombinantes produzidas artificialmente a partir de } \\
\text { genes clonados }\end{array}$ \\
\hline Itatijuca & $\begin{array}{c}\text { Especializada em processamento mineral, processos de extração, tratamento e drenagem de } \\
\text { minas }\end{array}$ \\
\hline Rheabiotech & $\begin{array}{c}\text { Especializada no desenvolvimento de soluções imunoquímicas para pesquisa e diagnóstico, } \\
\text { produção de anticorpos monoclonais, soros policioanais e anticorpos secundários conjugados }\end{array}$ \\
\hline
\end{tabular}

Figura 1. Lista de EBTs do setor de biotecnologia selecionadas.

Fonte: Elaborado pelos autores.

O roteiro de entrevista foi estruturado a partir dos modelos conceituais sobre capacidade relacional de McGrath (2008), Schilke e Goerzen (2010) e Alves (2015). O pré-teste do roteiro de entrevista foi realizado com pesquisadores, professores e gestores que atuam na área de inovação e desenvolvimento de novos produtos em junho de 2016. Uma vez pré-testado o 
instrumento, as entrevistas ocorreram in loco no período de outubro a novembro de 2016, quando foram gravadas e, posteriormente, transcritas.

Depois de coletados os dados, foi utilizada a análise de conteúdo, que, segundo Chizzotti (2010), é uma técnica que procura reduzir o volume amplo de informações contidas em uma comunicação a algumas características particulares ou categorias conceituais que permitam passar dos elementos descritivos à interpretação.

Para contribuir com a análise de conteúdo, foi utilizado o Iramuteq "Interface de R pour les Analyses Multidimensionnelles de Textes et de Questionnaires", que é um software desenvolvido por Ratinaud (2009). Trata-se de um programa informático gratuito que "permite diferentes formas de análises estatísticas sobre corpus textuais e sobre tabelas de indivíduos por palavras" (Camargo \& Justo, 2013).

O software Iramuteq possibilita os seguintes tipos de análises: estatísticas textuais clássicas, pesquisa de especificidades de grupos, classificação hierárquica descendente, análises de similitude e nuvem de palavras. Camargo e Justo (2013, p. 513) ressaltam que o IRAMUTEQ pode trazer muitas contribuições aos "estudos em ciências humanas e sociais que têm o conteúdo simbólico proveniente dos materiais textuais como uma fonte importante de dados de pesquisa", bem como "pelo seu rigor estatístico, pelas diferentes possibilidades de análise, interface simples e compreensível, e, sobretudo por seu acesso gratuito".

A figura 2 sintetiza o delineamento metodológico da pesquisa.

\begin{tabular}{|l|l|}
\hline Delineamento Metodológico \\
\hline Natureza da pesquisa & Qualitativa (Biklen \& Bogdan, 1994; Richardson, 1999). \\
\hline Abordagem metodológica & Descritiva (Barros \& Lehfeld, 2007). \\
\hline Método & Estudo de caso múltiplo (Yin, 2010). \\
\hline Unidade de análise & EBTs de biotecnologia. \\
\hline $\begin{array}{l}\text { Técnicas de coleta de } \\
\text { dados }\end{array}$ & Realização de entrevista estruturada (Yin, 2010). \\
\hline $\begin{array}{l}\text { Instrumentos de coleta de } \\
\text { dados }\end{array}$ & Roteiro de entrevistas estruturada (Yin, 2010). \\
\hline $\begin{array}{l}\text { Análise dos dados } \\
\text { Principais perguntas de } \\
\text { pesquisa que orientaram o } \\
\text { roteiro de entrevista e o } \\
\text { roteiro de análise } \\
\text { documental }\end{array}$ & $\begin{array}{l}\text { Análise de conteúdo e estratégia analítica baseada em proposições teóricas (Bardin, 1979) } \\
\text { Jusilização do software Iramuteq para recuperação de corpus textuais e palavras (Camargo \& }\end{array}$ \\
\hline $\begin{array}{l}\text { Como os objetivos estratégicos são definidos nas alianças estratégicas contratuais firmadas para o } \\
\text { DNP? Como são estruturadas as alianças estratégicas contratuais focadas no DNP? Como são } \\
\text { coordenadas as alianças estratégicas contratuais focadas no DNP? Como se configuram as } \\
\text { contribuições das alianças estratégicas contratuais firmadas para o DNP em EBTs? }\end{array}$ \\
\hline Perfil dos entrevistados & $\begin{array}{l}\text { Sócia e diretora de desenvolvimento de novos negócios da Empresa Biotika, a Diretora de } \\
\text { desenvolvimento de produtos e novos negócios da empresa Gentros, o Sócio e diretor de } \\
\text { desenvolvimento de novos negócios da empresa Itatijuca e a Sócia e diretora de desenvolvimento } \\
\text { de produtos e negócios da empresa Rheabiotech. }\end{array}$ \\
\hline
\end{tabular}

Figura 2. Delineamento Metodológico.

Fonte: Elaborado pelos autores. 


\section{Resultados e discussões sobre a geração de inovações e a capacidade relacional}

As organizações investigadas se reconhecem como empresas de base tecnológica (104 incidências no Iramuteq), cuja objetivo estratégico de maior incidência foi o desenvolvimento de novos produtos (104 incidências no Iramuteq) (Figura 3).

A Biotika trabalha na intermediação e prospecção de produtos que irão compor o produto de seus clientes, ou seja, faz todo o desenvolvimento que, em princípio, seus clientes não teriam condições científicas ou, até mesmo, tecnológicas de conduzir, precisando, portanto, de uma empresa que seja especialista em soluções biotecnológicas. Pode-se considerar que o entregável da Biotika é para o cliente uma subparte do produto final, porém para a Biotika é um produto (Figura 3).

Já a Gentros adota um modelo de negócio que consiste na identificação de novas tecnologias desenvolvidas nas instituições científicas e tecnológicas (ICTs), que possuem potencial de DNP. A Gentros desenvolve a tecnologia, já a produção e a comercialização são realizadas por outras empresas do setor. A transferência de tecnologia para essas empresas ocorre por meio de um acordo de parceria ou licenciamento do produto (Figura 3).

Em relação à principal proposta do modelo de negócio da Itatijuca, destaca-se o desenvolvimento de produtos e insumos biotecnológicos, bom como a prestação de um serviço inédito no Brasil denominado biolixiviação. Para esse serviço, foi realizada uma parceria com a Pöyry, empresa de consultoria e serviços de engenharia de origem finlandesa. Toda a metodologia de bioxiliviação foi desenvolvida pela Itatijuca, além disso, a empresa é responsável por realizar desde as provas de conceito até o acompanhamento da operação de biolixiviação. Já a Pöyry, por sua vez, atua na parte de engenharia, como em futuras plantas industriais e piloto de bioxiliviação (Figura 3).

O modelo de negócios da Rheabiotech segue três diretrizes. A primeira é a produção de insumos para pesquisa e desenvolvimento (anticorpos policlonais e monoclonais primários e secundários, anticorpos conjugados e proteínas recombinantes); a segunda é o desenvolvimento de kits diagnósticos para as áreas agrícola, veterinária e de saúde humana; e a terceira é a prestação de serviços na área imunoquímica (Figura 3). 


\begin{tabular}{|c|c|c|c|c|}
\hline $\begin{array}{l}\text { Categorias de } \\
\text { análise }\end{array}$ & Biotika & Gentros & Itatijuca & Rheabiotech \\
\hline $\begin{array}{l}\text { Modelo de } \\
\text { negócios para o } \\
\text { desenvolvimento } \\
\text { de novos } \\
\text { produtos }\end{array}$ & $\begin{array}{l}\text { Busca de insumos, } \\
\text { desenvolvimento, } \\
\text { adequação de } \\
\text { processo, acordo de } \\
\text { confidencialidade e } \\
\text { comercialização. }\end{array}$ & $\begin{array}{l}\text { Basicamente } \\
\text { acordos de } \\
\text { confidencialidade e } \\
\text { um contrato para o } \\
\text { desenvolvimento e } \\
\text { outro para a } \\
\text { comercialização. }\end{array}$ & $\begin{array}{l}\text { Utiliza uma } \\
\text { metodologia } \\
\text { desenvolvida pela } \\
\text { própria empresa, } \\
\text { baseado no "Stage } \\
\text { Gate" com nove } \\
\text { portões de decisões. }\end{array}$ & $\begin{array}{l}\text { Três etapas: acordo de } \\
\text { confidencialidade, } \\
\text { acordo de } \\
\text { desenvolvimento e } \\
\text { acordo comercial. }\end{array}$ \\
\hline $\begin{array}{l}\text { Principais } \\
\text { produtos ou } \\
\text { serviços ofertados }\end{array}$ & $\begin{array}{l}\text { Representação de } \\
\text { produtos } \\
\text { relacionados à } \\
\text { DNA/RNA, } \\
\text { proteínas e } \\
\text { moléculas, cultura } \\
\text { de células e tecidos } \\
\text { de bioengenharia; } \\
\text { além disso, presta } \\
\text { serviços no que } \\
\text { tange à transferência } \\
\text { de tecnologia. }\end{array}$ & $\begin{array}{l}\text { Diagnóstico } \\
\text { molecular, vacinas e } \\
\text { sequenciamento } \\
\text { genético. }\end{array}$ & $\begin{array}{l}\text { Tratamento de } \\
\text { minérios, rejeitos e } \\
\text { efluentes de difícil } \\
\text { gestão; tratamentos de } \\
\text { resíduos no setor de } \\
\text { papel e celulose; } \\
\text { recuperação de } \\
\text { resíduos eletrônicos; } \\
\text { controles biológicos na } \\
\text { agroindústria, entre } \\
\text { outros. }\end{array}$ & $\begin{array}{l}\text { Anticorpos primários } \\
\text { e secundários, } \\
\text { proteínas } \\
\text { recombinantes e kits } \\
\text { de diagnósticos. }\end{array}$ \\
\hline $\begin{array}{l}\text { Principais } \\
\text { parceiros } \\
\text { comerciais ou } \\
\text { representações }\end{array}$ & $\begin{array}{l}\text { Empresas do } \\
\text { exterior, incluindo } \\
\text { EUA, Alemanha, } \\
\text { França, Reino } \\
\text { Unido, Dinamarca e } \\
\text { Israel. }\end{array}$ & Empresas do setor. & $\begin{array}{l}\text { Pöyry (empresa } \\
\text { finlandesa) e Esalqtec } \\
\text { (Incubadora } \\
\text { Tecnológica). }\end{array}$ & $\begin{array}{l}\text { Universidades } \\
\text { brasileiras, institutos } \\
\text { de pesquisas e } \\
\text { empresas privadas e } \\
\text { estatais. }\end{array}$ \\
\hline $\begin{array}{l}\text { Recuperação de } \\
\text { corpus textuais e } \\
\text { palavras a partir } \\
\text { do software } \\
\text { Iramuteq }\end{array}$ & $\begin{array}{l}\text { 'Produto', com } 47 \\
\text { ocorrências; } \\
\text { 'empresa', com } 36 \text {; } \\
\text { 'mercado', com } 2 \text {; } \\
\text { 'patente', com } 22 \text {; } \\
\text { 'conhecimento', } \\
\text { com } 21 \text {; 'cliente', } \\
\text { com } 18 \text {; 'projeto', } \\
\text { com } 15 \text {. }\end{array}$ & $\begin{array}{l}\text { 'Empresa' e } \\
\text { 'produto', com } 27 \\
\text { ocorrências; } \\
\text { 'desenvolver', com } \\
24 ; \text { 'conhecimento', } \\
\text { com } 22 \text {; } \\
\text { 'desenvolvimento', } \\
\text { com 19; 'patente', } \\
\text { com } 18 .\end{array}$ & $\begin{array}{l}\text { 'Desenvolvimento', } \\
\text { com } 26 \text { ocorrências; } \\
\text { 'projeto', com 23; } \\
\text { ‘empresa', com 22; } \\
\text { 'desenvolver', com 15; } \\
\text { 'parceria' e 'produto', } \\
\text { com } 12 \text { ocorrências } \\
\text { cada. }\end{array}$ & $\begin{array}{l}\text { 'Trabalhar', com } 31 \\
\text { ocorrências; } \\
\text { 'produto', com 24; } \\
\text { 'projeto', com 21; } \\
\text { 'empresa', com 19; } \\
\text { 'desenvolvimento', } \\
\text { com 18; 'parceria', } \\
\text { com 17; 'mercado', } \\
\text { com 15; 'patente', } \\
\text { com } 14 \text { ocorrências. }\end{array}$ \\
\hline
\end{tabular}

Figura 3. Principais características das EBTs investigadas.

Fonte: Elaborado pelos autores.

\subsection{Biotika Biotecnologia}

A Biotika Biotecnologia é uma empresa de base tecnológica que destina aproximadamente $15 \%$ do seu faturamento às atividades de $\mathrm{P} \& \mathrm{D}$.

Como a Biotika oferta produtos a partir de representações, há um ritmo de lançamentos de novos produtos que, segundo a Sra. Catherine David, sócia e diretora de pesquisa e desenvolvimento, alcança o número de três a quatro produtos totalmente inovadores lançados por ano. O portfólio de produtos da empresa alcança cinco mil produtos. 
A empresa não possui nenhuma patente, por outro lado, observa que, se uma pequena empresa de biotecnologia desenvolve um processo que tem valor de mercado, deve registrar uma patente.

A Biotika não possui convênio permanente firmado com parceiros científicos e tecnológicos, mas é fundamental a vivência e experiência científicas e tecnológicas que a Sra. Catherine David tem junto aos pesquisadores que atuam no setor de biotecnologia no Brasil e exterior. A empresa possui parceiros junto ao polo tecnológico de Grenoble, na França.

$\mathrm{Na}$ Biotika o planejamento estratégico, é definido em função das tendências científicas e mercadológicas e com especial atenção às empresas que tenham propostas inovadoras e objetivem fechar alguma distribuição de produtos no Brasil. Nessa etapa, os dois sócios estão diretamente envolvidos no processo.

A coordenação das atividades e a sincronização das decisões de desenvolvimento da empresa com seus parceiros, independentemente de ser somente um ou vários, é realizada pela Sra. Catherine David, [...]reuniões são organizadas e planejadas tendo em vista definir as prioridades e necessidades previamente estabelecidas a partir de matriz de responsabilidade de que constam os prazos de execução das atividades [...].

Atualmente, a Biotika se encontra em processo de parceria com aproximadamente 25 empresas, sendo três ou quatro preponderantes. Desse modo, se não houver uma eficiência na coordenação das atividades e sincronização das decisões, não se consegue obter resultados positivos. Nesse ponto a Sra. Catherine David observa: [...] tem que organizar as informações direito! Fazer uma coisa de cada vez e organizar a informação à medida que ela vai chegando $[\ldots]$.

A coordenação das atividades e sincronização das decisões relativas ao processo de desenvolvimento também são realizadas pela Sra. Catherine David, que redistribui internamente as decisões tomadas junto aos parceiros e as repassa, considerando as responsabilidades de cada departamento, ajustando os projetos em execução que integram o portfólio de alianças estratégicas de acordo com o cronograma de trabalho da equipe técnica.

$\mathrm{Na}$ etapa de coordenação das atividades e sincronização das decisões internas, há necessidade constante de formalização e alinhamento das decisões entre as diretorias de desenvolvimento de novos produtos, comercial e equipe técnica e segundo a Sra. Catherine David, [...] tanto meu sócio quanto eu, nós formalizamos tudo, as nossas responsabilidades são muito bem definidas [...]. 
A troca de conhecimento é intensa entre a empresa e os parceiros nesse segmento. A própria Sra. Catherine David, muitas vezes, ao longo da entrevista, disse se tratar de um "segmento do conhecimento", e por isso reforça: [...] É importante o envolvimento de todos, até mesmo porque a empresa é pequena, a qualificação das pessoas ajuda neste processo como no caso da nossa área de vendas, onde todos são mestres e doutores em biologia, isso facilita muito também a disseminação dos conhecimentos dentro da empresa [...].

Após desenvolvimento e quando o produto já está finalmente concluído e pronto para entrar no mercado, a diretora de desenvolvimento emite, em uma planilha Excel, toda a descrição do produto, o código do fornecedor, o valor com que será vendido para que a equipe de São Paulo cadastre a referência no sistema. Nas palavras da Sra. Catherine David: [...] eu não cadastro nada no sistema, eu mando as informações para a equipe do escritório em São Paulo e aí eles cadastram, dão código, eu estou fora desse processo [...].

Até o momento, não houve nenhum caso de conflito e a Sra. Catherine David avalia que nesse mercado os acordos de confidencialidade constituem uma boa prática de negócios; no entanto, reforça que tanto os seus parceiros quanto a própria Biotika são cuidadosos em não abrir o conteúdo das alianças com outros concorrentes ou competidores.

Há na empresa a prática continuada de estabelecimento de alianças, o que tem contribuído de modo significativo para o aperfeiçoamento das rotinas de trabalho e dos processos organizacionais que envolvem a gestão das alianças estratégicas de desenvolvimento de novos produtos. A esse respeito, Sra. Catherine David enfatiza: [...] toda semana tem um novo projeto! [...].

A Sra. Catherine David também destaca a importância das alianças para sua empresa: [...] nós estamos totalmente dependentes dessas parcerias, realmente é o coração do nosso negócio! [...]. Ao falar sobre a importância de desenvolver a capacidade relacional da empresa, a Sra. Catherine David é enfática: [...] Vivemos de relacionamento! [...]. E essa prática, segundo ela, contribui de forma substancial para o desenvolvimento de um recurso muito importante para a empresa, que é o conhecimento, e ressalta: [...] "Estamos em uma indústria de conhecimentos $[\ldots]$. 
A figura 4 sintetiza a capacidade relacional na Biotika.

\begin{tabular}{|c|c|}
\hline $\begin{array}{l}\text { Gestão da capacidade relacional para o } \\
\text { desenvolvimento de novos produtos }\end{array}$ & Descrição da empresa Biotika \\
\hline $\begin{array}{l}\text { Número de alianças estratégicas (ativas) de } \\
\text { desenvolvimento de novos produtos } \\
\text { estabelecidas com parceiros externos }\end{array}$ & $\begin{array}{l}25 \text { alianças envolvendo parceiros de representação } \\
\text { nacionais e internacionais para desenvolvimento de } \\
\text { produtos }\end{array}$ \\
\hline $\begin{array}{l}\text { Definição de objetivos em alianças estratégicas } \\
\text { para o desenvolvimento de novos produtos }\end{array}$ & $\begin{array}{l}\text { São acompanhados pelos sócios da empresa e originados } \\
\text { das demandas de insumos e de serviços técnicos } \\
\text { especializados evidenciadas pelos parceiros tecnológicos e } \\
\text { comerciais }\end{array}$ \\
\hline $\begin{array}{l}\text { Mecanismos de prospecção de parceiros } \\
\text { externos para o desenvolvimento de novos } \\
\text { produtos }\end{array}$ & $\begin{array}{l}\text { Plataforma tecnológica (Webinar), rede de representações } \\
\text { comerciais e contatos profissionais e acadêmicos dos } \\
\text { gestores são fundamentais na prospecção de parceiros }\end{array}$ \\
\hline $\begin{array}{l}\text { Mecanismos de formalização das alianças } \\
\text { estratégicas de desenvolvimento de novos } \\
\text { produtos }\end{array}$ & Acordos de confidencialidade e contratos \\
\hline $\begin{array}{l}\text { Estrutura de gestão das alianças estratégicas de } \\
\text { desenvolvimento de novos produtos }\end{array}$ & $\begin{array}{l}\text { Envolve a diretoria de desenvolvimento de novos produtos } \\
\text { e negócios, a diretoria comercial e equipes de vendas }\end{array}$ \\
\hline $\begin{array}{l}\text { Atividades de sincronização das decisões de } \\
\text { desenvolvimento de novos produtos no } \\
\text { contexto das alianças estratégicas }\end{array}$ & $\begin{array}{l}\text { Sincronização interna das decisões entre as diretorias de } \\
\text { desenvolvimento de novos produtos, comercial e equipe } \\
\text { técnica que são registradas em atas de reunião }\end{array}$ \\
\hline $\begin{array}{l}\text { Atividades de coordenação de cada aliança } \\
\text { estratégica firmada para o desenvolvimento de } \\
\text { novos produtos }\end{array}$ & $\begin{array}{l}\text { Utilização de matriz de responsabilidade onde constam os } \\
\text { prazos de execução das atividades e reuniões internas com } \\
\text { os colaboradores e externas com os parceiros. }\end{array}$ \\
\hline $\begin{array}{l}\text { Atividades de coordenação do portfólio de } \\
\text { alianças estratégicas firmadas para o } \\
\text { desenvolvimento de novos produtos }\end{array}$ & $\begin{array}{l}\text { Centrada na diretoria de desenvolvimento de novos } \\
\text { produtos, ajustando os projetos em execução que integram } \\
\text { o portfólio de alianças estratégicas de acordo com o } \\
\text { cronograma de trabalho da equipe técnica interna }\end{array}$ \\
\hline $\begin{array}{l}\text { Mecanismos de troca de conhecimento entre a } \\
\text { empresa e seus parceiros externos para o } \\
\text { desenvolvimento de novos produtos }\end{array}$ & $\begin{array}{l}\text { Resultados entregáveis e os conhecimentos decorrentes das } \\
\text { alianças são registrados em atas de reunião compartilhadas } \\
\text { entre a empresa e seus parceiros. }\end{array}$ \\
\hline $\begin{array}{l}\text { Mecanismos de disseminação entre as áreas da } \\
\text { empresa dos conhecimentos adquiridos a partir } \\
\text { de alianças estratégicas de desenvolvimento de } \\
\text { novos produtos }\end{array}$ & $\begin{array}{l}\text { Os conhecimentos adquiridos são disseminados em } \\
\text { reuniões internas e são armazenados eletronicamente, não } \\
\text { havendo um padrão preestabelecido de registro interno. }\end{array}$ \\
\hline $\begin{array}{l}\text { Projetos de inovação de produto gerados a } \\
\text { partir dos conhecimentos adquiridos nas } \\
\text { alianças estratégicas }\end{array}$ & $\begin{array}{l}\text { Conhecimentos adquiridos de experiências anteriores } \\
\text { foram utilizados em projetos de desenvolvimento de novos } \\
\text { produtos. }\end{array}$ \\
\hline $\begin{array}{l}\text { Competências geradas a partir das alianças } \\
\text { estratégicas de desenvolvimento de novos } \\
\text { produtos }\end{array}$ & Prática continuada de estabelecimento de alianças. \\
\hline $\begin{array}{l}\text { Mecanismos de resolução de conflitos de } \\
\text { interesses em alianças estratégicas de } \\
\text { desenvolvimento de novos produtos }\end{array}$ & Não houve nenhum caso explícito de conflito. \\
\hline $\begin{array}{l}\text { Contribuições da experiência no } \\
\text { estabelecimento de alianças estratégicas de } \\
\text { novos produtos }\end{array}$ & $\begin{array}{l}\text { Aperfeiçoamento das rotinas de trabalho e dos processos } \\
\text { organizacionais que envolvem a gestão das alianças } \\
\text { estratégicas de novos produtos. }\end{array}$ \\
\hline $\begin{array}{l}\text { Modelo de negócios fundamentado em } \\
\text { parcerias externas para inovação }\end{array}$ & $\begin{array}{l}\text { Modelo de negócio da empresa é sustentado pela aquisição } \\
\text { contínua de novos conhecimentos. }\end{array}$ \\
\hline
\end{tabular}

Figura 4. Síntese da capacidade relacional na Biotika.

Fonte: Elaborado pelos autores. 


\subsection{Gentros}

A Gentros ainda não possui patentes em seu portfólio de produtos, porém considera estratégico e necessário obter as patentes para a linha de vacinas que estão sendo desenvolvidas no mercado. Seus principais parceiros e clientes estão dentro das universidades, nas palavras da Sra. Paula Araújo, sócia e diretora de novos negócios: [...] A universidade é um grande celeiro de oportunidades [...]. A empresa mantém vínculos de relacionamento com as universidades e centros de pesquisa e nos últimos três anos, desenvolveu dois produtos tecnologicamente inovadores e um processo (meta genômica) que está em pleno desenvolvimento.

A empresa não destina nenhuma parte do seu faturamento a algum centro de pesquisa ou universidade, porém mantém uma parceria com a Universidade Estadual de Campinas, que viabiliza o uso de seus laboratórios, quando necessário, cobrando somente pelo tempo de utilização e pelos materiais utilizados.

Atualmente a Gentros está envolvida em duas parcerias com duas universidades, a Unifesp e a Unesp, para o desenvolvimento de novos produtos.

Nas universidades geralmente as empresas tem que passar pelo Núcleo de Inovação Tecnológica e esse é o caminho utilizado pela Gentros, mediante acordos de confidencialidade e contratos. É um processo sempre formal, no caso da Unesp segundo a Sra. Paula Araújo há um contrato que prevê a consultoria do professor pesquisador e quando sair a patente uma parte vai para eles.

Toda a coordenação das atividades está a cargo da Sra. Paula Araújo, que explica: [...] A gente tem sempre conversas semanais e, às vezes, quinzenais com o parceiro, realizamos reuniões para definir o quanto andou e o que não andou, porque não andou e para redirecionar o tempo, recalcular aquele tempo que foi perdido em coisas repetidas[...].

Questionada sobre que tipo de conhecimento a Gentros procura em seus parceiros, a Sra. Paula Araújo esclareceu que a busca é por conhecimento nas áreas em que a empresa não atua diretamente, como por exemplo, teste clínico e comenta que existe um "gap", um vazio entre a universidade que gera o conhecimento e a empresa que precisa produzir e colocar o produto no mercado: [...] "Este espaço é onde as empresas de biotecnologia estão atuando para fazer esta ponte $[\ldots]$.

A sincronização das decisões tomadas nesse processo, seja interna ou externa, também está a cargo da Sra. Paula Araújo e explica que é necessário que haja um comprometimento 
para que o produto saia no tempo adequado para ambas empresas. Para tanto, há reuniões semanais ou quinzenais para verificar e definir o andamento dos projetos e redirecionar caso seja necessário, relata ainda que não existe um documento formal para o registro das reuniões, mas as decisões são todas registradas em atas que serão distribuídas às empresas.

Não existe um departamento formal para o gerenciamento dessas atividades, que estão centradas na atuação da Sra. Paula Araújo: [...] nas empresas de biotecnologia, geralmente o departamento é um, quem gerencia vê o negócio como um todo, no nosso caso em específico, eu faço tudo sozinha [...]. Esclarece, ainda, que, quando se finaliza um desenvolvimento, ele é registrado em um relatório final que tem que ser assinado novamente por ambas as partes.

A troca de conhecimentos entre a Gentros e os parceiros externos segundo a Sra. Paula Araújo se dá por via eletrônica, e-mails, artigos científicos e protocolos. Trocamos muito protocolo entre as empresas; você faz uma coisa e eu faço outra, tudo isso reforçado pelas reuniões semanais ou quinzenais [...]. Internamente o processo é muito mais simples, por se tratar somente de um funcionário interno que organiza todas as informações pertinentes, até por isso não existe um procedimento formal para essa atividade [...].

Segundo a Sra. Paula Araújo, as parcerias contribuem para que a empresa adquira novas competências tecnológicas, seja a partir de uma nova técnica ou um novo padrão de protocolo de pesquisa e relata que, até o momento, não houve nenhum problema de conflito.

Com relação à prática contínua das alianças, a Sra. Paula Araújo comenta: [...] Nós entendemos que a prática de fazer parcerias para o desenvolvimento de novos produtos contribui muito para a nossa capacidade relacional, a experiência adquirida também contribui muito para que consigamos nos relacionar de forma cada vez melhor com nossos parceiros [...], e reforça: [...] algumas parcerias apresentam resultados tão positivos que direciona você para outros produtos e outros tipos de parcerias; isso cresce e ajuda muito na confiança de ambos os lados e faz com que outros produtos surjam [...].

A figura 5 sintetiza a capacidade relacional na Gentros.

\begin{tabular}{|l|l|}
\hline $\begin{array}{l}\text { Gestão da capacidade relacional para o } \\
\text { desenvolvimento de novos produtos }\end{array}$ & Descrição da empresa Gentros \\
\hline $\begin{array}{l}\text { Número de alianças estratégicas (ativas) de } \\
\text { desenvolvimento de novos produtos estabelecidos } \\
\text { com parceiros externos. }\end{array}$ & Duas parcerias: Unesp e Unifesp. \\
\hline $\begin{array}{l}\text { Definição de objetivos em alianças estratégicas } \\
\text { para o desenvolvimento de novos produtos. }\end{array}$ & $\begin{array}{l}\text { Realizada conjuntamente entre os sócios e tem como } \\
\text { fundamento o desenvolvimento de produtos e processos } \\
\text { tecnologicamente inovadores. }\end{array}$ \\
\hline $\begin{array}{l}\text { Mecanismos de prospecção de parceiros externos } \\
\text { para o desenvolvimento de novos produtos. }\end{array}$ & $\begin{array}{l}\text { Rede de relacionamento dos gestores e uma plataforma } \\
\text { virtual chamada ResearchGate. }\end{array}$ \\
\hline
\end{tabular}




\begin{tabular}{|c|c|}
\hline $\begin{array}{l}\text { Mecanismos de formalização das alianças } \\
\text { estratégicas de desenvolvimento de novos } \\
\text { produtos. }\end{array}$ & Acordos de confidencialidade e contratos. \\
\hline $\begin{array}{l}\text { Estrutura de gestão das alianças estratégicas de } \\
\text { desenvolvimento de novos produtos. }\end{array}$ & $\begin{array}{l}\text { A estrutura está centrada na diretoria de } \\
\text { desenvolvimento de produtos e negócios. }\end{array}$ \\
\hline $\begin{array}{l}\text { Atividades de sincronização das decisões de } \\
\text { desenvolvimento de novos produtos no contexto } \\
\text { das alianças estratégicas. }\end{array}$ & $\begin{array}{l}\text { Reuniões semanais ou quinzenais envolvendo a empresa } \\
\text { e seus parceiros são realizadas para acompanhar o } \\
\text { andamento ou redirecionamento das atividades de } \\
\text { desenvolvimento. }\end{array}$ \\
\hline $\begin{array}{l}\text { Atividades de coordenação de cada aliança } \\
\text { estratégica firmada para o desenvolvimento de } \\
\text { novos produtos. }\end{array}$ & $\begin{array}{l}\text { Reuniões periódicas com o parceiro para troca de } \\
\text { informações técnicas. }\end{array}$ \\
\hline $\begin{array}{l}\text { Atividades de coordenação do portfólio de alianças } \\
\text { estratégicas firmadas para o desenvolvimento de } \\
\text { novos produtos. }\end{array}$ & Não são realizadas pela empresa. \\
\hline $\begin{array}{l}\text { Mecanismos de troca de conhecimento entre a } \\
\text { empresa e seus parceiros externos para o } \\
\text { desenvolvimento de novos produtos. }\end{array}$ & $\begin{array}{l}\text { Reuniões, troca de e-mails, compartilhamento de atas de } \\
\text { reunião e do relatório final dos produtos desenvolvidos. }\end{array}$ \\
\hline $\begin{array}{l}\text { Mecanismos de disseminação entre as áreas da } \\
\text { empresa dos conhecimentos adquiridos a partir de } \\
\text { alianças estratégicas de desenvolvimento de novos } \\
\text { produtos. }\end{array}$ & Reuniões internas. \\
\hline $\begin{array}{l}\text { Projetos de inovação de produto gerados a partir } \\
\text { dos conhecimentos adquiridos nas alianças } \\
\text { estratégicas. }\end{array}$ & Novos desenvolvimentos de vacinas. \\
\hline $\begin{array}{l}\text { Competências geradas a partir das alianças } \\
\text { estratégicas de desenvolvimento de novos } \\
\text { produtos. }\end{array}$ & Padronização de novos protocolos de pesquisa. \\
\hline $\begin{array}{l}\text { Mecanismos de resolução de conflitos de interesses } \\
\text { em alianças estratégicas de desenvolvimento de } \\
\text { novos produtos. }\end{array}$ & $\begin{array}{l}\text { Ainda não houve um caso de conflito explícito, mas } \\
\text { busca-se eliminar ou minimizar a partir dos acordos } \\
\text { estabelecidos previamente. }\end{array}$ \\
\hline $\begin{array}{l}\text { Contribuições da prática continuada (experiência) } \\
\text { no estabelecimento de alianças estratégicas de } \\
\text { novos produtos. }\end{array}$ & $\begin{array}{l}\text { Capacita a empresa para se relacionar melhor com os } \\
\text { parceiros. }\end{array}$ \\
\hline $\begin{array}{l}\text { Modelo de negócios fundamentado em parcerias } \\
\text { externas para inovação. }\end{array}$ & $\begin{array}{l}\text { Utilização de parcerias externas para busca de } \\
\text { competências tecnológicas e para padronização de } \\
\text { protocolos de pesquisa. }\end{array}$ \\
\hline
\end{tabular}

Figura 5. Síntese da capacidade relacional na Gentros.

Fonte: Elaborado pelos autores

\subsection{Itatijuca Biotech}

A Itatijuca declara ter desenvolvido quatro novos produtos nos últimos três anos, nem todos estão sendo comercializados, além de dois novos processos tecnológicos para seus produtos. Não possui até o momento nenhum faturamento que esteja atrelado a algum produto que tenha patente, mas informa que já tem um pedido de patente encaminhado. É interessante observar o que o Sr. Rafael Ferreira, sócio e diretor de desenvolvimento de novos produtos comenta a respeito das patentes no mercado de biotecnologia: [...] na biotecnologia não é 
permitido o patenteamento de micro-organismos, então a gente usa muito o segredo industrial como forma de se proteger [...].

Para as atividades de P\&D, a empresa destina, aproximadamente, $10 \%$ do seu faturamento, e para os institutos e centros de pesquisa como USP, Instituto de Pesquisas Energéticas e Nucleares, Unesp e Esalq/USP, que são, inclusive, seus principais parceiros, são destinados, em média, aproximadamente, 30\%. Já trabalha com fomentos provenientes principalmente da Fapesp.

A Itatijuca entende que o desenvolvimento de produtos no segmento de biotecnologia é realizado de forma colaborativa, ou seja, a busca por parceiros é fundamental nessa etapa para que se possa agilizar, flexibilizar e aperfeiçoar os processos na busca por inovação. Nas palavras do próprio Sr. Rafael Ferreira: [...] vou te dizer que é fundamental, as alianças são fundamentais para que a gente possa se desenvolver. É impossível uma empresa de biotecnologia crescer sem ter parceria $[\ldots]$.

Finalizadas as fases de planejamento e prospecção de oportunidades, já com as prioridades de desenvolvimento estabelecidas e os acordos formalizados junto aos parceiros, passa-se para as fases de coordenação dessas atividades. Nessa etapa, são estabelecidas as rotinas formais de gestão que devem estar pré-determinadas nos contratos, e como relata o próprio Sr. Rafael Ferreira: [...] nós temos um contrato, por meio do contrato aí tem um acompanhamento da gestão do desenvolvimento [...].

Internamente a coordenação das atividades é desenvolvida a partir de reuniões periódicas em que o andamento do desenvolvimento do novo produto é repassado para toda a equipe.

No contexto das alianças, a coordenação é realizada a partir de reuniões e dependendo das prioridades, esses encontros podem ser mensais. Os resultados das reuniões são formalizados em atas. Nas palavras do Sr. Rafael Ferreira: [...] não existe reunião sem ata [...].

As decisões das reuniões são repassadas a todos os envolvidos por meio de relatórios descritivos e distribuídos entre os parceiros. São designados líderes em cada empresa para facilitar e otimizar os entregáveis e, no caso da Itatijuca, essa função é realizada pelo Sr. Rafael Ferreira. Destaca-se, ainda, a utilização de matriz de responsabilidade, envolvendo o detalhamento dos prazos e das atribuições da Itatijuca e dos respectivos parceiros envolvidos no desenvolvimento dos novos produtos.

A Itatijuca se encontra em processos de parceria ativa de desenvolvimento com sete empresas, portanto a gestão dessas parcerias é fundamental para a eficácia do processo. Sendo o Sr. Rafael Ferreira coordenador e líder da Itatijuca, compete a ele toda a dinâmica de 
coordenação e sincronização interna e externa. A esse respeito ressalta: [...] é importante definir a pauta, montar as apresentações e ir para as reuniões de trabalho [...].

As propostas de desenvolvimento de novos produtos, a partir de alianças estratégicas, são elaboradas pela própria Itatijuca e são submetidas à apreciação dos parceiros.

O Sr. Rafael Ferreira comenta que a prática contínua de alianças estratégicas de desenvolvimento de novos produtos contribui para que a empresa adquira experiência e melhore seus processos internos e o relacionamento com os parceiros, bem como minimiza a possibilidade de conflitos e comenta que, até o momento, não surgiu nenhum problema específico.

Dentre as diversas alianças estratégicas até aqui estabelecidas pela Itatijuca, a mais relevante e que abriu portas para outros negócios foi a estabelecida com a empresa Pöyry. Foi desenvolvido um processo denominado "biolixiviação" para ser utilizado no setor de mineração brasileiro, alternativa considerada muito sustentável.

A metodologia de biolixiviação foi desenvolvida pela Itatijuca que ficou responsável pela realização desde as provas de conceito até o acompanhamento da operação normal de biolixiviação. A Pöyry será o braço de engenharia nessa parceria.

Ressaltando as palavras finais do Sr. Rafael Ferreira: [...] é importante olhar a "Biotec" como um todo interagindo como se fosse um ecossistema: entre entidades governamentais, universidades, empresas, pesquisadores e até alunos de graduação [...]. Ele destaca que esse ecossistema ainda "é verde" e precisa amadurecer. As políticas públicas de fomento ainda são insuficientes e estão muito aquém do que o sistema precisa: [...] hoje a gente participa de um ecossistema que permite que a gente tenha, que cria oportunidades para novas parcerias. Então, hoje a gente faz parte de um ecossistema que é fundamental para a nossa sobrevivência [...].

A figura 6 sintetiza a capacidade relacional na Itatijuca. 


\begin{tabular}{|c|c|}
\hline $\begin{array}{l}\text { Gestão da capacidade relacional para o desenvolvimento de } \\
\text { novos produtos }\end{array}$ & Descrição da empresa Itatijuca \\
\hline $\begin{array}{l}\text { Número de alianças estratégicas (ativas) de desenvolvimento de } \\
\text { novos produtos estabelecidas com parceiros externos. }\end{array}$ & 7 \\
\hline $\begin{array}{l}\text { Definição de objetivos em alianças estratégicas para o } \\
\text { desenvolvimento de novos produtos. }\end{array}$ & $\begin{array}{l}\text { Elaborados pelos sócios da empresa e } \\
\text { fundamentados no fornecimento de } \\
\text { soluções tecnológicas baseadas em } \\
\text { biotecnologia e química verde. }\end{array}$ \\
\hline $\begin{array}{l}\text { Mecanismos de prospecção de parceiros externos para o } \\
\text { desenvolvimento de novos produtos. }\end{array}$ & Plataforma tecnológica (Itec). \\
\hline $\begin{array}{l}\text { Mecanismos de formalização das alianças estratégicas de } \\
\text { desenvolvimento de novos produtos. }\end{array}$ & $\begin{array}{l}\text { Acordos de confidencialidade e } \\
\text { contratos. }\end{array}$ \\
\hline $\begin{array}{l}\text { Estrutura de gestão das alianças estratégicas de desenvolvimento } \\
\text { de novos produtos. }\end{array}$ & $\begin{array}{l}\text { Centrada no diretor de } \\
\text { desenvolvimento de novos produtos e } \\
\text { negócios. }\end{array}$ \\
\hline $\begin{array}{l}\text { Atividades de sincronização das decisões de desenvolvimento de } \\
\text { novos produtos no contexto das alianças estratégicas. }\end{array}$ & $\begin{array}{l}\text { A sincronização das decisões se dá a } \\
\text { partir de reuniões internas semanais } \\
\text { formalizadas e registradas em atas para } \\
\text { facilitar que os colaboradores internos } \\
\text { possam acompanhar as últimas } \\
\text { decisões. }\end{array}$ \\
\hline $\begin{array}{l}\text { Atividades de coordenação de cada aliança estratégica firmada } \\
\text { para o desenvolvimento de novos produtos. }\end{array}$ & $\begin{array}{l}\text { Reuniões internas com os } \\
\text { colaboradores e externas com os } \\
\text { parceiros. }\end{array}$ \\
\hline $\begin{array}{l}\text { Atividades de coordenação do portfólio de alianças estratégicas } \\
\text { firmadas para o desenvolvimento de novos produtos. }\end{array}$ & $\begin{array}{l}\text { Está centrada no diretor de } \\
\text { desenvolvimento de novos produtos e } \\
\text { negócios. }\end{array}$ \\
\hline $\begin{array}{l}\text { Mecanismos de troca de conhecimento entre a empresa e seus } \\
\text { parceiros externos para o desenvolvimento de novos produtos. }\end{array}$ & $\begin{array}{l}\text { Reuniões de trabalho junto aos } \\
\text { parceiros. }\end{array}$ \\
\hline $\begin{array}{l}\text { Mecanismos de disseminação entre as áreas da empresa dos } \\
\text { conhecimentos adquiridos a partir de alianças estratégicas de } \\
\text { desenvolvimento de novos produtos. }\end{array}$ & $\begin{array}{l}\text { Reuniões internas com as definições de } \\
\text { responsabilidades e prazos para os } \\
\text { entregáveis registrados em atas. }\end{array}$ \\
\hline $\begin{array}{l}\text { Projetos de inovação de produto gerados a partir dos } \\
\text { conhecimentos adquiridos nas alianças estratégicas. }\end{array}$ & $\begin{array}{l}\text { Foi mencionado com projeto na } \\
\text { temática papel de celulose. }\end{array}$ \\
\hline $\begin{array}{l}\text { Competências geradas a partir das alianças estratégicas de } \\
\text { desenvolvimento de novos produtos. }\end{array}$ & $\begin{array}{l}\text { Conhecimentos específicos que a } \\
\text { empresa até então não possuía. }\end{array}$ \\
\hline $\begin{array}{l}\text { Mecanismos de resolução de conflitos de interesses em alianças } \\
\text { estratégicas de desenvolvimento de novos produtos. }\end{array}$ & $\begin{array}{l}\text { Não houve nenhum caso explícito de } \\
\text { conflito. }\end{array}$ \\
\hline $\begin{array}{l}\text { Contribuições da prática continuada (experiência) no } \\
\text { estabelecimento de alianças estratégicas de novos produtos. }\end{array}$ & $\begin{array}{l}\text { Fornece conhecimentos novos e gera } \\
\text { competências para o estabelecimento } \\
\text { de novas parcerias. }\end{array}$ \\
\hline $\begin{array}{l}\text { Modelo de negócios fundamentado em parcerias externas para } \\
\text { inovação. }\end{array}$ & $\begin{array}{l}\text { Mostrou-se fundamental para o modelo } \\
\text { de negócio da empresa que é baseado } \\
\text { na popularização e divulgação aberta da } \\
\text { tecnologia desenvolvida. }\end{array}$ \\
\hline
\end{tabular}

Figura 6. Síntese da capacidade relacional na empresa Itatijuca.

Fonte: Elaborado pelos autores

\subsection{Rheabiotech}

A Rheabiotech já possui uma patente resultante de um produto desenvolvido a partir do fomento da Fapesp, mas que ainda não está sendo comercializado. Nos últimos três anos, foram desenvolvidos quatro produtos, sendo dois já lançados e dois finalizados, mas ainda não 
disponíveis no mercado. Destaca-se que, para cada um desses produtos, foram desenvolvidos também novos processos, o que contribui para a aprendizagem de novas tecnologias.

A empresa possui em seu portfólio mais de 500 produtos no mercado e, segundo a Sra. Fernanda Rojas, sócia e diretora de pesquisa e desenvolvimento muitos dos produtos são desenvolvidos especificamente para um professor, por exemplo, que precisa de algum tipo particular de insumo. No momento, há três produtos com valor agregado maior e que estão em processo de prototipagem. Nessa etapa, a Sra. Fernanda Rojas esclareceu a forma de trabalho da Rheabiotech: [...] A gente tem dois grupos de trabalho sim, um que é produção permanente de insumo para pesquisa de desenvolvimento: a gente faz cotação, fechamento de pedido e ficha cadastral. O outro trabalho envolve projetos que podem levar de dois a três anos e esses projetos normalmente são vinculados à Fapesp ou Finep, e são demorados mesmo [...].

A empresa não destina nenhuma parte do seu faturamento para as atividades de P\&D. Até o momento tem utilizado a modalidade de subvenção em projetos aprovados pela Fapesp ou Finep. Nas palavras da própria Sra. Fernanda Rojas: [...] lamentavelmente não temos, não por falta de vontade $[\ldots]$.

Sobre a questão de a patente ser fundamental nos negócios da empresa, a Sra. Fernanda Rojas respondeu: [...] olha! Eu particularmente acho que as patentes só servem para as grandes empresas comercializarem. Assim, o que é importante para nós em ter a patente é porque chama a atenção do mercado para nossa empresa. $\mathrm{O}$ investidor quando vem conversar com a gente, a primeira pergunta é essa: "Vocês têm patentes"? "Tem chances de ter patente"? A patente hoje em dia é muito valorizada em termos financeiros, então as empresas, os investidores enxergam como uma coisa viável se você tem patente, ou se o produto é patenteável [...].

Dada a flexibilidade para se adequar às necessidades dos clientes, a dinâmica de contato e relacionamento junto aos pesquisadores e universidades é intenso. Esse trabalho, conforme dito anteriormente, é desenvolvido predominantemente pela Sra. Fernanda Rojas e, em suas palavras: [...] geralmente sou eu mesmo que faço! [...]. Não há um departamento formal ou estrutura específica para essas atividades.

A coordenação das atividades e sincronização das decisões também é realizada pela Sra. Fernando Rojas e o processo ocorre basicamente pela troca de e-mails ou ainda a partir de conversas pelo Skype. Se as partes julgarem necessário, é então agendada uma reunião presencial para verificar as pendências, como os contatos basicamente são entre empresas 
pequenas e pesquisadores é montado um cronograma de trabalho para que se possa acompanhar os resultados.

Internamente o alinhamento das informações e a disseminação dos conhecimentos ficam a cargo dos sócios. A diretora de desenvolvimento cuida dos conhecimentos e informações advindas dos parceiros e o outro sócio cuida dos conhecimentos e informações técnicas relativas ao laboratório. A Sra. Fernando Rojas reforçou: [...] as alianças estratégicas estabelecidas complementam internamente os nossos negócios, pois as pequenas empresas parceiras também desenvolvem produtos novos e toda a interação leva geralmente a um conhecimento novo que, potencialmente, poderá ser reutilizado em outras plataformas de desenvolvimento, sempre com foco na geração de solução completa para o cliente [...].

Apesar de haver um volume significativo de desenvolvimento de novos produtos e, possivelmente, futuras parcerias, a Rheabiotech particulariza a gestão das alianças estratégicas. Segundo a Sra. Fernanda Rojas, ainda não há uma carteira constituída, as alianças são conduzidas individualmente, seus principais clientes são as universidades e os pesquisadores.

Até o momento não houve nenhum caso de conflito de interesses entre a empresa e seus parceiros externos.

As parcerias para o desenvolvimento de novos produtos a partir de alianças são, segundo a Sra. Fernanda Rojas, de fundamental importância: [...] desde que eu comecei a empresa que eu falo, nenhuma empresa, pelo menos neste país, em nosso segmento, vai funcionar se não se associar, se complementar e unir forças [...].

A Sra. Fernanda Rojas também é muito enfática na sequência do comentário: [...] Eu acho que não somos concorrentes, não competimos uma com as outras, a gente só tende a somar nessas parcerias, eu tenho essa teoria". Ela finaliza dizendo que a prática continuada de alianças, mesmo as que não deram certo, servem para que a empresa desenvolva sua capacidade de relacionamento com outras empresas, "sempre somando, a gente não tem nada a esconder, não temos esta política, não temos que ficar resguardados, muito pelo contrário, então é enriquecedor para todas as partes o contato com os parceiros externos [...]. 
A figura7 sintetiza a capacidade relacional na Rheabiotech.

\begin{tabular}{|c|c|}
\hline $\begin{array}{l}\text { Gestão da capacidade relacional para o } \\
\text { desenvolvimento de novos produtos }\end{array}$ & Descrição da empresa Rheabiotech \\
\hline $\begin{array}{l}\text { Número de alianças estratégicas (ativas) de } \\
\text { desenvolvimento de novos produtos estabelecidas com } \\
\text { parceiros externos. }\end{array}$ & $\begin{array}{l}\text { A empresa não possui uma carteira de } \\
\text { alianças, seus projetos são conduzidos } \\
\text { individualmente. }\end{array}$ \\
\hline $\begin{array}{l}\text { Definição de objetivos em alianças estratégicas para o } \\
\text { desenvolvimento de novos produtos. }\end{array}$ & $\begin{array}{l}\text { Depende das competências de cada parceiro e } \\
\text { das suas respectivas demandas por soluções } \\
\text { imunoquímicas de pesquisa e de diagnóstico. }\end{array}$ \\
\hline $\begin{array}{l}\text { Mecanismos de prospecção de parceiros externos para o } \\
\text { desenvolvimento de novos produtos. }\end{array}$ & $\begin{array}{l}\text { Participa de feiras e eventos na área, mas } \\
\text { trabalha principalmente por demanda. }\end{array}$ \\
\hline $\begin{array}{l}\text { Mecanismos de formalização das alianças estratégicas de } \\
\text { desenvolvimento de novos produtos. }\end{array}$ & $\begin{array}{l}\text { Acordos de confidencialidade, contratos e } \\
\text { acordos comerciais. }\end{array}$ \\
\hline $\begin{array}{l}\text { Estrutura de gestão das alianças estratégicas de } \\
\text { desenvolvimento de novos produtos. }\end{array}$ & $\begin{array}{l}\text { Centrada no diretor de desenvolvimento de } \\
\text { novos produtos e mercados. }\end{array}$ \\
\hline $\begin{array}{l}\text { Atividades de sincronização das decisões de } \\
\text { desenvolvimento de novos produtos no contexto das } \\
\text { alianças estratégicas. }\end{array}$ & $\begin{array}{l}\text { É estabelecido um cronograma de trabalho } \\
\text { entre a empresa e seus parceiros para que se } \\
\text { possam sincronizar as decisões e acompanhar } \\
\text { os resultados a partir de reuniões. }\end{array}$ \\
\hline $\begin{array}{l}\text { Atividades de coordenação de cada aliança estratégica } \\
\text { firmada para o desenvolvimento de novos produtos. }\end{array}$ & Internet, Skype, $e$-mail e reuniões. \\
\hline $\begin{array}{l}\text { Atividades de coordenação do portfólio de alianças } \\
\text { estratégicas firmadas para o desenvolvimento de novos } \\
\text { produtos. }\end{array}$ & Ainda não há um portfólio de alianças. \\
\hline $\begin{array}{l}\text { Mecanismos de troca de conhecimento entre a empresa e } \\
\text { seus parceiros externos para o desenvolvimento de novos } \\
\text { produtos. }\end{array}$ & $\begin{array}{l}\text { Há diversas formas, foi citado um caso } \\
\text { (Embrapa) em que uma apresentação gerou } \\
\text { um contato para o desenvolvimento de um } \\
\text { novo produto. }\end{array}$ \\
\hline $\begin{array}{l}\text { Mecanismos de disseminação entre as áreas da empresa } \\
\text { dos conhecimentos adquiridos a partir de alianças } \\
\text { estratégicas de desenvolvimento de novos produtos. }\end{array}$ & Reuniões internas. \\
\hline $\begin{array}{l}\text { Projetos de inovação de produto gerados a partir dos } \\
\text { conhecimentos adquiridos nas alianças estratégicas. }\end{array}$ & $\begin{array}{l}\text { Foi citado o caso de biosensores que gerou } \\
\text { outras oportunidades de projetos inovadores. }\end{array}$ \\
\hline $\begin{array}{l}\text { Competências geradas a partir das alianças estratégicas } \\
\text { de desenvolvimento de novos produtos. }\end{array}$ & $\begin{array}{l}\text { Reutilização de conhecimentos absorvidos nas } \\
\text { alianças estratégicas em outras plataformas de } \\
\text { desenvolvimento. }\end{array}$ \\
\hline $\begin{array}{l}\text { Mecanismos de resolução de conflitos de interesses em } \\
\text { alianças estratégicas de desenvolvimento de novos } \\
\text { produtos. }\end{array}$ & $\begin{array}{l}\text { Os conflitos que surgiram foram somente os } \\
\text { de rotina técnica e comercial. }\end{array}$ \\
\hline $\begin{array}{l}\text { Contribuições da prática continuada (experiência) no } \\
\text { estabelecimento de alianças estratégicas de novos } \\
\text { produtos. }\end{array}$ & $\begin{array}{l}\text { Os acertos e erros fortalecem o aprendizado, } \\
\text { capacitando a empresa e seus parceiros no que } \\
\text { tange à gestão das futuras alianças. }\end{array}$ \\
\hline $\begin{array}{l}\text { Modelo de negócios fundamentado em parcerias externas } \\
\text { para inovação. }\end{array}$ & $\begin{array}{l}\text { É fundamental para os negócios da empresa e } \\
\text { seus parceiros a união de forças, dado que a } \\
\text { dinâmica do mercado de biotecnologia depende } \\
\text { de associações e complementações. }\end{array}$ \\
\hline
\end{tabular}

Figura 7. Síntese da capacidade relacional na empresa Rheabiotech.

Fonte: Elaborado pelos autores. 


\section{Conclusão e Considerações Finais}

A questão central de pesquisa do estudo, bem como os objetivos e perguntas de pesquisa decorrentes, ativeram-se a analisar como a capacidade relacional pode contribuir para a geração de inovações em EBTs, sendo assim, a conclusão foi de que a capacidade relacional desempenha um papel fundamental para a agregação de valor ao modelo de negócios fundamentado em alianças estratégicas contratuais. Sendo assim, foi possível sintetizar na figura 8 as propriedades descritoras da capacidade relacional que estimularam e sistematizaram a geração de inovações nas EBTs investigadas.

\begin{tabular}{|c|c|c|c|c|}
\hline \multirow{2}{*}{$\begin{array}{l}\text { Propriedades } \\
\text { descritoras da } \\
\text { capacidade } \\
\text { relacional }\end{array}$} & \multicolumn{4}{|c|}{ Evidências obtidas no campo } \\
\hline & Biotika & Gentros & Itatijuca & Rheabiotech \\
\hline $\begin{array}{l}\text { (1)* A prospecção de } \\
\text { oportunidades } \\
\text { tecnológicas e } \\
\text { mercadológicas } \\
\text { (McGrath, 2008; } \\
\text { Schilke \& Goerzen, } \\
\text { 2010) }\end{array}$ & $\begin{array}{l}\text { Prospecção se dá } \\
\text { nos âmbitos } \\
\text { nacional e } \\
\text { internacional. }\end{array}$ & $\begin{array}{l}\text { Prospecção se dá } \\
\text { nos âmbitos } \\
\text { nacional e } \\
\text { internacional. }\end{array}$ & $\begin{array}{l}\text { Prospecção se dá no } \\
\text { setor como um todo } \\
\text { em nível nacional. }\end{array}$ & $\begin{array}{l}\text { Prospecção se dá } \\
\text { nos âmbitos } \\
\text { nacional e } \\
\text { internacional. }\end{array}$ \\
\hline $\begin{array}{l}(2)^{*} \text { A } \\
\text { fundamentação de } \\
\text { objetivos estratégicos } \\
\text { para inovação } \\
\text { (Schilke \& Goerzen, } \\
\text { 2010) }\end{array}$ & $\begin{array}{l}\text { Objetivo } \\
\text { fundamental é } \\
\text { atender às } \\
\text { demandas por } \\
\text { insumos e } \\
\text { serviços técnicos } \\
\text { especializados já } \\
\text { sinalizadas pelos } \\
\text { parceiros. } \\
\text { tecnológicos e } \\
\text { comerciais. }\end{array}$ & $\begin{array}{l}\text { Objetivo } \\
\text { fundamental é o } \\
\text { desenvolvimento de } \\
\text { produtos e } \\
\text { processos } \\
\text { tecnologicamente } \\
\text { inovadores. }\end{array}$ & $\begin{array}{l}\text { Objetivo } \\
\text { fundamental é o } \\
\text { fornecimento de } \\
\text { soluções } \\
\text { tecnológicas } \\
\text { baseadas em } \\
\text { biotecnologia e } \\
\text { química verde. }\end{array}$ & $\begin{array}{l}\text { Depende das } \\
\text { competências de } \\
\text { cada parceiro e das } \\
\text { suas respectivas } \\
\text { demandas por } \\
\text { soluções } \\
\text { imunoquímicas de } \\
\text { pesquisa e de } \\
\text { diagnóstico. }\end{array}$ \\
\hline $\begin{array}{l}(3) * * \text { A priorização } \\
\text { de investimentos em } \\
\text { P\&D interno e } \\
\text { colaborativo (em } \\
\text { ICTs) }\end{array}$ & $\begin{array}{l}15 \% \text { do } \\
\text { faturamento da } \\
\text { empresa são } \\
\text { destinados ao } \\
\text { P\&D interno. }\end{array}$ & $\begin{array}{l}\text { O que se fatura é } \\
\text { quase que na } \\
\text { totalidade } \\
\text { direcionado ao P\&D } \\
\text { interno. }\end{array}$ & $\begin{array}{l}10 \% \text { do faturamento } \\
\text { da empresa são } \\
\text { destinados ao P\&D } \\
\text { interno. }\end{array}$ & $\begin{array}{l}\text { No P\&D interno } \\
\text { utiliza-se a } \\
\text { modalidade de } \\
\text { subvenção em } \\
\text { projetos aprovados } \\
\text { pela Fapesp ou } \\
\text { Finep. }\end{array}$ \\
\hline $\begin{array}{l}(4)^{* *} \text { A priorização } \\
\text { de investimentos em } \\
\text { P\&D colaborativo } \\
\text { (em ICTs) }\end{array}$ & $\begin{array}{l}0 \% \text { do } \\
\text { faturamento da } \\
\text { empresa é } \\
\text { destinado às } \\
\text { ICT.) }\end{array}$ & $\begin{array}{l}0 \% \text { do faturamento } \\
\text { da empresa é } \\
\text { destinado às ICTs. }\end{array}$ & $\begin{array}{l}30 \% \text { do faturamento } \\
\text { da empresa são } \\
\text { destinados às ICTs } \\
\text { para o } \\
\text { desenvolvimento } \\
\text { colaborativo de } \\
\text { novos produtos. }\end{array}$ & $\begin{array}{l}0 \% \text { do faturamento } \\
\text { da empresa é } \\
\text { destinado às ICTs. }\end{array}$ \\
\hline $\begin{array}{l}(5)^{* *} \text { A alocação de } \\
\text { recursos humanos } \\
\text { qualificados para } \\
\text { geração de inovação }\end{array}$ & $\begin{array}{l}\text { Todos os } \\
\text { profissionais que } \\
\text { atuam no } \\
\text { desenvolvimento } \\
\text { de novos } \\
\text { produtos são }\end{array}$ & $\begin{array}{l}\text { Todos os } \\
\text { profissionais que } \\
\text { atuam no } \\
\text { desenvolvimento de } \\
\text { novos produtos são } \\
\text { titulados, sendo três }\end{array}$ & $\begin{array}{l}\text { Todos os } \\
\text { profissionais que } \\
\text { atuam no } \\
\text { desenvolvimento de } \\
\text { novos produtos são } \\
\text { titulados, sendo } 10\end{array}$ & $\begin{array}{l}\text { Todos os } \\
\text { profissionais que } \\
\text { atuam no } \\
\text { desenvolvimento de } \\
\text { novos produtos são } \\
\text { titulados, sendo dois }\end{array}$ \\
\hline
\end{tabular}




\begin{tabular}{|c|c|c|c|c|}
\hline & $\begin{array}{l}\text { titulados, sendo } \\
\text { um graduado e } \\
\text { três com } \\
\text { mestrado e/ou } \\
\text { doutorado. }\end{array}$ & $\begin{array}{l}\text { graduados e dois } \\
\text { com mestrado e/ou } \\
\text { doutorado. }\end{array}$ & $\begin{array}{l}\text { graduados e sete } \\
\text { com mestrado e/ou } \\
\text { doutorado. }\end{array}$ & $\begin{array}{l}\text { graduados e dois } \\
\text { com mestrado e/ou } \\
\text { doutorado. }\end{array}$ \\
\hline $\begin{array}{l}(6) * \text { A prospecção } \\
\text { ativa de parceiros } \\
\text { externos (McGrath, } \\
2008)\end{array}$ & $\begin{array}{l}\text { Plataforma } \\
\text { tecnológica } \\
\text { Webinar, rede de } \\
\text { representações } \\
\text { comerciais e } \\
\text { contatos } \\
\text { profissionais e } \\
\text { acadêmicos dos } \\
\text { gestores são } \\
\text { fundamentais na } \\
\text { prospecção de } \\
\text { parceiros. }\end{array}$ & $\begin{array}{l}\text { Rede de } \\
\text { relacionamento dos } \\
\text { gestores e uma } \\
\text { plataforma virtual } \\
\text { chamada Research } \\
\text { Gate são } \\
\text { fundamentais na } \\
\text { prospecção de } \\
\text { parceiros. }\end{array}$ & $\begin{array}{l}\text { Plataforma } \\
\text { tecnológica (Itec) é } \\
\text { fundamental na } \\
\text { prospecção de } \\
\text { parceiros. }\end{array}$ & $\begin{array}{l}\text { Participa de feiras e } \\
\text { eventos na área, mas } \\
\text { trabalha } \\
\text { principalmente por } \\
\text { demanda. }\end{array}$ \\
\hline $\begin{array}{l}\text { (7)* A formalização } \\
\text { de alianças } \\
\text { estratégicas } \\
\text { contratuais } \\
\text { (McGrath, 2008; } \\
\text { Schilke \& Goerzen, } \\
\text { 2010; Alves, 2015) }\end{array}$ & $\begin{array}{l}\text { Estabelecimento } \\
\text { de acordos de } \\
\text { confidencialidade } \\
\text { e contratos. }\end{array}$ & $\begin{array}{l}\text { Estabelecimento de } \\
\text { acordos de } \\
\text { confidencialidade e } \\
\text { contratos. }\end{array}$ & $\begin{array}{l}\text { Estabelecimento de } \\
\text { acordos de } \\
\text { confidencialidade e } \\
\text { contratos. }\end{array}$ & $\begin{array}{l}\text { Estabelecimento de } \\
\text { acordos de } \\
\text { confidencialidade, } \\
\text { contratos e acordos } \\
\text { comerciais. }\end{array}$ \\
\hline $\begin{array}{l}(8) * \text { A sistematização } \\
\text { de equipe para } \\
\text { gestão } \\
\text { compartilhada das } \\
\text { alianças (Schilke \& } \\
\text { Goerzen, 2010; Alves, } \\
2015 \text { ) }\end{array}$ & $\begin{array}{l}\text { Envolvimento } \\
\text { sistematizado da } \\
\text { diretoria de } \\
\text { desenvolvimento } \\
\text { de novos } \\
\text { produtos e } \\
\text { negócios, da } \\
\text { diretoria } \\
\text { comercial e das } \\
\text { equipes de } \\
\text { vendas. }\end{array}$ & $\begin{array}{l}\text { Centralizada na } \\
\text { diretoria de } \\
\text { desenvolvimento de } \\
\text { produtos e negócios. }\end{array}$ & $\begin{array}{l}\text { Centralizada na } \\
\text { diretoria de } \\
\text { desenvolvimento de } \\
\text { produtos e negócios. }\end{array}$ & $\begin{array}{l}\text { Centralizada na } \\
\text { diretoria de } \\
\text { desenvolvimento de } \\
\text { novos produtos e } \\
\text { mercados. }\end{array}$ \\
\hline $\begin{array}{l}\text { (9)* A disseminação } \\
\text { dos conhecimentos } \\
\text { entre as áreas da } \\
\text { empresa (McGrath, } \\
\text { 2008; Schilke \& } \\
\text { Goerzen, 2010; Alves, } \\
\text { 2015) }\end{array}$ & $\begin{array}{l}\text { Os } \\
\text { conhecimentos } \\
\text { adquiridos são } \\
\text { disseminados em } \\
\text { reuniões internas } \\
\text { a cada dois } \\
\text { meses e são } \\
\text { armazenados } \\
\text { eletronicamente. }\end{array}$ & $\begin{array}{l}\text { Os conhecimentos } \\
\text { adquiridos são } \\
\text { disseminados em } \\
\text { reuniões internas. }\end{array}$ & $\begin{array}{l}\text { Reuniões internas } \\
\text { com as definições } \\
\text { de } \\
\text { responsabilidades e } \\
\text { prazos para os } \\
\text { entregáveis } \\
\text { registrados em atas. }\end{array}$ & $\begin{array}{l}\text { Os conhecimentos } \\
\text { adquiridos são } \\
\text { disseminados em } \\
\text { reuniões internas. }\end{array}$ \\
\hline $\begin{array}{l}\text { (10)* A coordenação } \\
\text { compartilhada da } \\
\text { carteira de aliança } \\
\text { (Schilke \& Goerzen, } \\
\text { 2010; Alves, 2015) }\end{array}$ & $\begin{array}{l}\text { Coordenação da } \\
\text { carteira de } \\
\text { alianças está } \\
\text { centrada na } \\
\text { diretoria de } \\
\text { desenvolvimento } \\
\text { de novos } \\
\text { produtos que } \\
\text { considera apenas } \\
\text { o cronograma de } \\
\text { trabalho da }\end{array}$ & $\begin{array}{l}\text { Não são realizadas } \\
\text { pela empresa } \\
\text { atividades de } \\
\text { coordenação da } \\
\text { carteira de alianças. }\end{array}$ & $\begin{array}{l}\text { Coordenação da } \\
\text { carteira de alianças } \\
\text { está centrada na } \\
\text { diretoria de } \\
\text { desenvolvimento de } \\
\text { produtos e negócios. }\end{array}$ & $\begin{array}{l}\text { Ainda não há um } \\
\text { portfólio de alianças. }\end{array}$ \\
\hline
\end{tabular}




\begin{tabular}{|c|c|c|c|c|}
\hline & $\begin{array}{l}\text { equipe técnica } \\
\text { interna. }\end{array}$ & & & \\
\hline $\begin{array}{l}(11) * * \text { A reutilização } \\
\text { de conhecimentos } \\
\text { para inovações } \\
\text { subsequentes }\end{array}$ & $\begin{array}{l}\text { Conhecimentos } \\
\text { adquiridos de } \\
\text { alianças } \\
\text { anteriores foram } \\
\text { reutilizados em } \\
\text { projetos de } \\
\text { desenvolvimento } \\
\text { de novos } \\
\text { produtos com a } \\
\text { Embrapa e a } \\
\text { Fiocruz. }\end{array}$ & $\begin{array}{l}\text { Conhecimentos } \\
\text { adquiridos de } \\
\text { alianças anteriores } \\
\text { foram reutilizados } \\
\text { em projetos de } \\
\text { desenvolvimento de } \\
\text { vacinas. }\end{array}$ & $\begin{array}{l}\text { Conhecimentos } \\
\text { adquiridos de } \\
\text { alianças anteriores } \\
\text { foram reutilizados } \\
\text { em projetos de } \\
\text { desenvolvimento } \\
\text { com a temática } \\
\text { papel e celulose. }\end{array}$ & $\begin{array}{l}\text { Conhecimentos } \\
\text { adquiridos de } \\
\text { alianças anteriores } \\
\text { sobre biossensores } \\
\text { foram reutilizados } \\
\text { em projetos de } \\
\text { desenvolvimento } \\
\text { recentes. }\end{array}$ \\
\hline $\begin{array}{l}(12)^{* *} \text { A } \\
\text { sincronização } \\
\text { compartilhada das } \\
\text { decisões de inovação }\end{array}$ & $\begin{array}{l}\text { Sincronização } \\
\text { das decisões é } \\
\text { interna, } \\
\text { envolvendo as } \\
\text { diretorias de } \\
\text { desenvolvimento } \\
\text { de novos } \\
\text { produtos, } \\
\text { comercial e } \\
\text { equipe técnica. }\end{array}$ & $\begin{array}{l}\text { Reuniões semanais } \\
\text { ou quinzenais } \\
\text { envolvendo a } \\
\text { empresa e seus } \\
\text { parceiros são } \\
\text { realizadas para } \\
\text { acompanhar o } \\
\text { andamento ou } \\
\text { decidir quanto ao } \\
\text { redirecionamento } \\
\text { das atividades de } \\
\text { desenvolvimento. }\end{array}$ & $\begin{array}{l}\text { Sincronização das } \\
\text { decisões se dá a } \\
\text { partir de reuniões } \\
\text { internas semanais } \\
\text { formalizadas e } \\
\text { registradas em atas } \\
\text { para facilitar que os } \\
\text { colaboradores } \\
\text { internos possam } \\
\text { acompanhar as } \\
\text { últimas decisões. }\end{array}$ & $\begin{array}{l}\text { Estabelecimento de } \\
\text { um cronograma de } \\
\text { trabalho entre a } \\
\text { empresa e seus } \\
\text { parceiros para que } \\
\text { se possam } \\
\text { sincronizar as } \\
\text { decisões e } \\
\text { acompanhar os } \\
\text { resultados a partir de } \\
\text { reuniões. }\end{array}$ \\
\hline $\begin{array}{l}(13)^{* *} \text { A adoção de } \\
\text { modelo de negócios } \\
\text { fundamentado em } \\
\text { inovação aberta e } \\
\text { colaborativa }\end{array}$ & $\begin{array}{l}\text { Modelo de } \\
\text { negócio da } \\
\text { empresa é } \\
\text { sustentado pela } \\
\text { aquisição } \\
\text { contínua de } \\
\text { novos } \\
\text { conhecimentos. }\end{array}$ & $\begin{array}{l}\text { Utilização de } \\
\text { parcerias externas } \\
\text { para busca de } \\
\text { competências } \\
\text { tecnológicas e para } \\
\text { padronização de } \\
\text { protocolos de } \\
\text { pesquisa. }\end{array}$ & $\begin{array}{l}\text { Mostrou-se } \\
\text { fundamental para o } \\
\text { modelo de negócio } \\
\text { da empresa que é } \\
\text { baseado na } \\
\text { popularização e } \\
\text { divulgação aberta } \\
\text { da tecnologia } \\
\text { desenvolvida. }\end{array}$ & $\begin{array}{l}\text { É fundamental para } \\
\text { os negócios da } \\
\text { empresa e seus } \\
\text { parceiros a união de } \\
\text { forças, dado que a } \\
\text { dinâmica do } \\
\text { mercado de } \\
\text { biotecnologia } \\
\text { depende de } \\
\text { associações e } \\
\text { complementação. }\end{array}$ \\
\hline $\begin{array}{l}(14) * \text { A prática } \\
\text { continuada } \\
\text { (experiência) em } \\
\text { alianças estratégicas } \\
\text { para geração de } \\
\text { inovações (McGrath, } \\
\text { 2008; Schilke \& } \\
\text { Goerzen, 2010) }\end{array}$ & $\begin{array}{l}\text { Aperfeiçoamento } \\
\text { das rotinas de } \\
\text { trabalho e dos } \\
\text { processos } \\
\text { organizacionais } \\
\text { que envolvem a } \\
\text { gestão das } \\
\text { alianças } \\
\text { estratégicas de } \\
\text { novos produtos. }\end{array}$ & $\begin{array}{l}\text { Capacita a empresa } \\
\text { a se relacionar } \\
\text { melhor com os } \\
\text { parceiros. }\end{array}$ & $\begin{array}{l}\text { Fornece } \\
\text { conhecimentos } \\
\text { novos e gera } \\
\text { competências para o } \\
\text { estabelecimento de } \\
\text { novas parcerias. }\end{array}$ & $\begin{array}{l}\text { Os acertos e erros } \\
\text { fortalecem o } \\
\text { aprendizado, } \\
\text { capacitando a } \\
\text { empresa e seus } \\
\text { parceiros no que } \\
\text { tange à gestão das } \\
\text { futuras alianças. }\end{array}$ \\
\hline
\end{tabular}

Figura 8. Propriedades descritoras da capacidade relacional que estimularam e sistematizaram a geração de inovações nas EBTs investigadas.

Legenda: *Propriedades descritores da capacidade relacional previstas nos modelos teóricos de Schilke e Goerzen (2010), McGrath (2008) e Alves (2015); ** Propriedades descritores da capacidade relacional que emergiram do campo. Fonte: Elaborado pelos autores.

Vale acrescentar que as empresas pesquisadas têm uma atuação intensa na busca e prospecção de novas oportunidades para geração de inovações com o objetivo de trazer recursos complementares para dentro da própria empresa. 
Percebeu-se, também, uma proximidade significativa nas atividades que envolvem o planejamento estratégico e a geração de inovações. Observou-se que essas atividades se desenvolvem quase que simultaneamente nas empresas pesquisadas.

As EBTs investigadas possuem uma estrutura enxuta, desse modo, a diretoria de pesquisa e desenvolvimento se mostrou central à estruturação, tanto das práticas operacionais, quanto das práticas de gestão das alianças estratégicas contratuais estabelecidas para a geração de inovações.

Vale ressaltar que a inovação é um fator chave para as empresas de biotecnologia manteremse competitivas, conforme verificado nos resultados empíricos obtidos a partir desta pesquisa, pois estas empresas estão permanentemente transformando o conhecimento científico em novas tecnologias que serão posteriormente aplicadas em novos produtos e serviços inovativos.

Como se trata ainda de um campo em que a ciência é multidisciplinar, essas empresas trabalham em um sistema aberto, buscando por parceiros que possam oferecer recursos complementares, seja no campo científico ou tecnológico.

Neste cenário, o setor de biotecnologia torna-se um ambiente fértil para que as EBTs se mantenham em constante relacionamento. Logo, a forma como essas empresas promovem a interação organizacional é fundamental para a geração de inovações.

Como este trabalho possui a limitação de não oferecer evidências generalizáveis à uma amostra representativa de EBTs de biotecnologia brasileiras, é notória a relevância de se pensar em pesquisa quantitativas futuras a respeito da influência da capacidade relacional sobre o desempenho inovador das EBTs que estabelecem alianças com parceiros comerciais e tecnológicos.

\section{Referências}

Alves, F. S. (2015). Capacidades relacionais em cooperações para desenvolvimento de tecnologias com e sem fins lucrativos. Tese de doutorado, Universidade Federal do Paraná, Curitiba, PR, Brasil. Anderson, A. R., Benavides-Espinosa, M. del M., \& Mohedano-Suanes, A. (2011). Innovation in services through learning in a joint venture. The Service Industries Journal, 31(12), 2019-2032.

Bardin, L. (1979). Análise de conteúdo. Lisboa: Edições, 70.

Barros, A. J. D. S., \& Lehfeld, N. A. D. S. (2007). Fundamentos de metodologia científica. São Paulo, 2. Biklen, S. \& Bogdan, R. C. (1994). Investigação qualitativa em educação. Porto: Porto Ed., 134-301.

Banco Nacional de Desenvolvimento Econômico e Social - BNDES, 2014. Perspectivas do investimento 2015-2018 e panoramas setoriais. Disponível em: <http://www.pedbrasil.org.br/ped/artigos/2F11DABAD8B76964.pdf>. Acesso maio 2016.

Bueno, B. \& Balestrin, A. (2012). Collaborative innovation: an open approach in the development of new products. Revista de Administração de Empresas, 52(5), 517-530.

Camargo, Á. A. B. D. \& Meirelles, D. S. (2012). Capacidades Dinâmicas: o que são e como identificá-las. XXXVI Anpad. 
Camargo, B. V. \& Justo, A. M. (2013). IRAMUTEQ: um software gratuito para análisede dados textuais. Temas em Psicologia, 21(2), 513-518.

Chizzotti, A. (2010). Pesquisa em Ciências Humanas e Sociais. São Paulo: Cortez.

CEBRAP - Centro Brasileiro de Análise e Planejamento. Brazil Biotech Map de 2011. Disponível em: <http://cebrap.org.br/wp-content/uploads/2017/05/Brazil-Biotec-Map2011.pdf>. Acesso em Fevereiro de 2016.

Cooper, G. F. (1990). The computational complexity of probabilistic inference using Bayesian belief networks. Artificial intelligence, 42(2-3), 393-405.

Costa, P. R. da, Porto, G. S., \& Silva, A. T. B. da. (2012). Capacidades dinâmicas de inovação e cooperação: aspectos da trajetória e da maturidade das multinacionais brasileiras. In XV SEMEAD.

Cui, A. S., \& O'Connor, G. (2012). Alliance portfolio resource diversity and firm innovation. Journal of Marketing, 76(4), 24-43.

Delbufalo, E., \& Cerruti, C. (2012). Configuration and the capability of firms to innovate: A theoretical framework. International Journal of Management, 29(3), 16.

Donada, C., Nogatchewsky, G., \& Pezet, A. (2015). Understanding the relational dynamic capabilitybuilding process. Strategic Organization, 14(2), 93-117.

Dyer, J., \& Kale, P. (2007). Relational capabilities: drivers and implications. Dynamic capabilities, Understanding strategic change in organizations, 65-79.

Estrella, A., \& Bataglia, W. (2013). A influência da rede de alianças no crescimento das empresas de biotecnologia de saúde humana na indústria brasileira. Organizações \& Sociedade, 20(65).

Feller, J., Parhankangas, A., Smeds, R., \& Jaatinen, M. (2013). How companies to collaborate: Emergence of improved inter-organizational processes in R\&D alliances. Organization Studies, 34(3), 313-343.

Fernandes, A. C., Côrtes, M. R., \& Pinho, M. (2016). Caracterização das pequenas e médias empresas de base tecnológica em São Paulo: uma análise preliminar. Economia e Sociedade, 13(1), 151-173

Gibbons, R., \& Henderson, R. (2012). Relational contracts and organizational capabilities. Organization Science, 23(5), 1350-1364.

Heimeriks, K. H., \& Duysters, G. (2007). Alliance capability as a mediator between experience and alliance performance: An empirical investigation into the alliance capability development process. Journal of Management Studies,44(1), 25-49.

Heimeriks, K. H., \& Duysters, G. M. (2003). Experience and Capabilities to Explain Alliance Performance: Substitutes or Complements. Eindhoven Centre for Innovation Studies (ECIS), Eindhoven University of Technology, The Netherlands.

Helfat, C. E., Finkelstein, S., Mitchell, W., Peteraf, M., Singh, H., Teece, D., \& Winter, S. G. (2009). Dynamic Capabilities: Understanding strategic change in organizations. John Wiley \& Sons.

Kale, P.; Singh, H. (2007). Building firm capabilities through learning: the role of the alliance learning process in alliance capability and firm-level alliance success. Strategic Management Journal. 28 (10): 981-1000.

Koen, P., Ajamian, G., Burkart, R., Clamen, A., Davidson, J., D'Amore, R. \& Karol, R. (2001). Providing clarity and a common language to the "fuzzy front end". Research-Technology Management, 44(2), 46-55.

Lin, H., \& Darnall, N. (2015). Strategic alliance formation and structural configuration. Journal of Business Ethics, 127(3), 549-564.

Lorenzoni, G., \& Lipparini, A. (1999). The leveraging of interfirm relationships as a distinctive organizational capability: a longitudinal study. Strategic Management Journal, 20(4), 317-338.

McGrath, H. (2008). Developing a relational capability construct for SME network marketing using cases and evidence from Irish and Finnish SMEs (Doctoral dissertation, Waterford Institute of Technology). 
Niesten, E., \& Jolink, A. (2015). The impact of alliance management capabilities on alliance attributes and performance: a literature review. International Journal of Management Reviews, 17(1), 69-100.

OECD - Organização para a Cooperação e Desenvolvimento Econômico. A Framework for Biotechnology Statistics. OCDE, Paris, 2005.

Ortiz-de-Urbina-Criado, M., Montoro-Sánchez, Á., \& Mora-Valentín, E.-M. (2014). Impact of growth strategy on mode of governance in alliances. International Business Review, 23(4), 838-848.

Pisano, G. P. (1991). The governance of innovation: vertical integration and collaborative arrangements in the biotechnology industry. Research Policy,20(3), 237-249.

Pisano, G. P. (2006). Science business: the promise, the reality, and the future of biotech. Harvard Business Press. Chesbrough, H. (2003). The logic of open innovation: managing intellectual property. California Management Review, 45(3), 33-58.

Ratinaud, P. (2009). IRAMUTEQ: Interface de R pour les Analyses Multidimensionnelles de Textes et de Questionnaires [Computer software].

Richardson, R. J. (1999). Pesquisa Social: métodos e técnicas. São Paulo, Atlas.

Rozenfeld, H., Forcellini, F. A., Amaral, D. C., Toledo, J. C., Silva, S. L., Alliprandini, D. H., \& Scalice, R. K. (2006). Gestão de Desenvolvimento de Produtos: uma referência para a melhoria do Processo. $1^{\text {a }}$ edição. São Paulo: Saraiva.

Schilke, O., \& Goerzen, A. (2010). Alliance management capability: an investigation of the construct and its measurement. Journal of Management,36 (5), 1192-1219.

Teece, D. J. (2009). Dynamic capabilities and strategic management: Organizing for innovation and growth. Oxford University Press on Demand.

Teece, D. J., Pisano, G., \& Shuen, A. (1997). Dynamic capabilities and strategic management. Strategic management journal, 18 (7), 509-533.

Walsh, J. P., Lee, Y. N., \& Nagaoka, S. (2016). Openness and innovation in the US: Collaboration form, idea generation and implementation. Research Policy, 45(8), 1660-1671.

Walter, S. G., Walter, A., \& Müller, D. (2015). Formalization, communication quality, and opportunistic behavior in R\&D alliances between competitors. Journal of Product Innovation Management, 32(6), 954-970.

Wang, G., Dou, W., Zhu, W., \& Zhou, N. (2015). The effects of firm capabilities on external collaboration and performance: The moderating role of market turbulence. Journal of Business Research, 68(9), 1928-1936.

Wang, Y., \& Rajagopalan, N. (2015). Alliance capabilities review and research agenda. Journal of Management, 41(1), 236-260.

Yan, Y., Zhang, S. H., \& Zeng, F. (2010). The exploitation of an international firm's relational capabilities: an empirical study. Journal of Strategic Marketing, 18(6), 473-487.

Yin, R. K. (2010). Estudo de Caso: Planejamento e Métodos. Bookman editora.

Zollo, M., \& Winter, S. G. (2002). Deliberate learning and the evolution of dynamic capabilities. Organization science, 13 (3), 339-351. 